\title{
Extreme Hydrologic Events in North Area of Buenos Aires Province (Argentina)
}

\author{
Alberto Daniel Capriolo ${ }^{1}$ and Olga Eugenia Scarpati1,2 \\ ${ }^{1}$ National Research Council (CONICET), Buenos Aires Paraguay 2155, Ciudad Autonoma de Buenos Aires, \\ C1121ABG Buenos Aires, Argentina \\ ${ }^{2}$ Geography Department, La Plata National University, Calle 48 entre 6 y 7, 1900 La Plata, Argentina
}

Correspondence should be addressed to Alberto Daniel Capriolo, albertocapriolo@yahoo.com.ar

Received 28 September 2012; Accepted 16 October 2012

Academic Editors: L.-T. Hsieh, N. A. Mazzeo, and F. Tao

Copyright (C) 2012 A. D. Capriolo and O. E. Scarpati. This is an open access article distributed under the Creative Commons Attribution License, which permits unrestricted use, distribution, and reproduction in any medium, provided the original work is properly cited.

This paper presents the soil water deficit and soil water surplus obtained from soil water balance in three drainage areas of Buenos Aires province for the period from 1971 to 2010. The soil water balance had been performed using the evapotranspiration formula of Penman-Monteith and considering the soil water constants: field capacity, soil water moisture, and soil wilting point for all the different types of soils of the region. The obtained soil water deficit and surplus are considered as triggers of extreme hydrologic events. Annual threshold values of $200 \mathrm{~mm}$ of soil water deficit and $300 \mathrm{~mm}$ of soil water surplus were considered for drought and flood, respectively. It was found that almost the $25 \%$ of the floods are severe and extreme while the $50 \%$ of droughts were of these intensities. Mann-Kendall statistical test was performed, and significance trends at level 0.1 were found for drought and for two periods, one of twenty years (1991-2010) and the other of ten years (2001-2010). As a sample of the temporal evolution of both events and their trends, the results of one locality (Junin) were deeply analyzed.

\section{Introduction}

Buenos Aires province is located in the main rain-fed region of Argentina, the Pampean plain, and presents cities of different importance and population. The main soil uses rain-fed crops (maize, wheat, and soybean) and livestock for meat or milk production. Extreme hydrological events are a constant in the province, and their impacts mainly over the agriculture have been studied with different scales and points of view. The province is a large plain, and its surface is $307,571 \mathrm{~km}^{2}$.

In this paper, the study region is the north area of it, which is located between $33^{\circ}$ and $37^{\circ} \mathrm{S}$ and $60^{\circ}$ and $63^{\circ} 30^{\prime} \mathrm{W}$ and where mild and humid climate dominates.

In spite of the good yields of corn $(8,000 \mathrm{q} / \mathrm{ha})$ and wheat $(3,800 \mathrm{q} / \mathrm{ha})$, during the last years the surface dedicated to soybean $(3,500 \mathrm{q} / \mathrm{ha})$ has been increasing because it presents best economic opportunities.

Extreme hydrologic events (flood and drought) are persistent having a significant socioeconomic impact. Their study in terms of agrohydrologic conditions would help to understand by providing tools for management and forecasting.

The climatic anomalies, such as prolonged wet or dry periods, produce significant losses in agriculture and livestock and were well studied by different scholars as Labraga et al. [1], who analyzed the atmospheric circulation associated with the excesses and deficits of rain in the Argentine Pampean region.

Soil moisture is a significant hydrological variable related to floods and droughts, plays an important role in the process of converting precipitation into runoff and groundwater storage, and controls the interaction of the land with the atmosphere.

The drainage system of Buenos Aires province consists of meandering rivers that are partially connected to permanent and seasonal lagoons. The low regional gradient leads to the detention of rainwater for long periods, in various forms of storage, mainly in the soil, on the floodplain, and in shallow lagoons. This favours vertical water fluxes (evaporation and infiltration) rather than lateral runoff. The vertical hydrologic fluxes of rainfall and evapotranspiration are of 


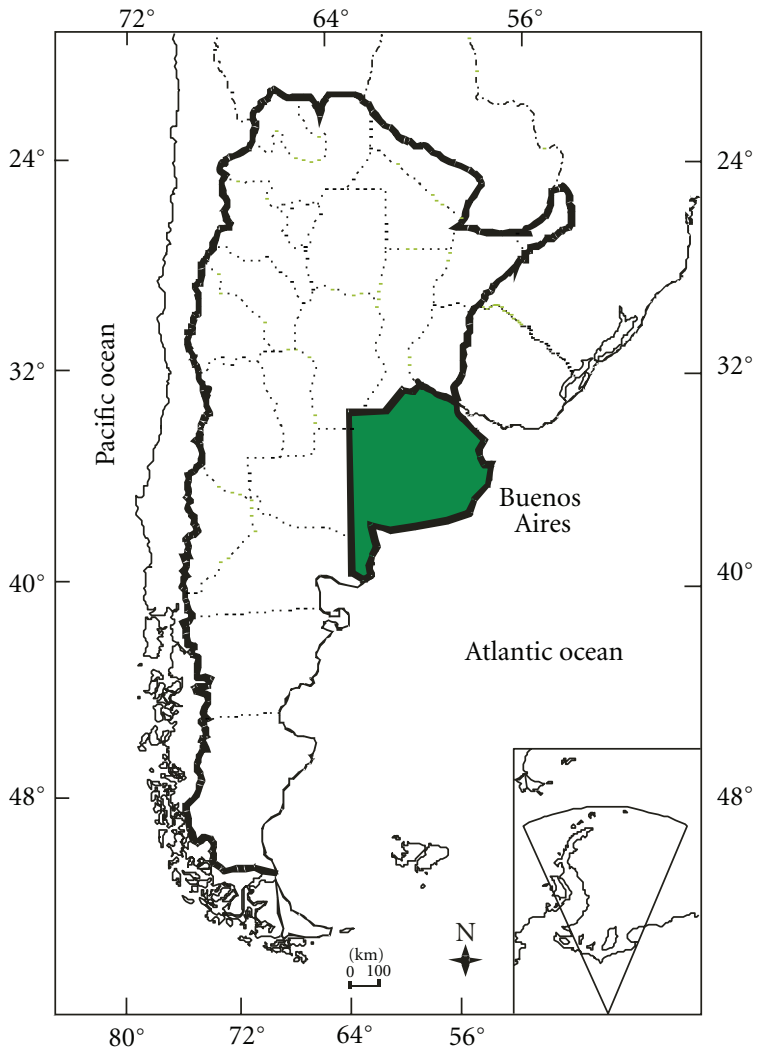

Figure 1: Location of Buenos Aires province, Argentina.

more concern in regions of limited relief, like the study area, than on horizontal surface and subsurface flows.

The soil water surplus is the quantity of rainwater that remains over the soil surface when the water infiltration is null because the soil storage capacity is achieved and occurs during periods with precipitation exceeding evapotranspiration. During such periods, once soil storage capacity is achieved, the soil water table is elevated. Eventually, the water surplus is unable to infiltrate because the water table is so close to the surface, a common occurrence in many low-lying areas of Buenos Aires province. The water table rises to the surface, thereby increasing the flood potential and the area of lakes, ponds, and surface impoundments. During the last decades, situation occurs more frequently as a result of the increased precipitation [2-4].

When water table is very close to the surface, this indicates that surface waters (ponds) and groundwater are strongly related, so they should be treated as part of a single system. The water table fluctuations are important indicators of hydrologic behavior. Kruse et al. [5] and Forte Lay et al. $[6,7]$ show the relation between the soil water balance and variations in the depth of the water table at different Pampean stations.

Drought is a period of abnormally dry weather sufficiently prolonged for the lack of precipitation to cause a serious hydrological imbalance [8].

Drought is a natural, reoccurring, and worldwide phenomenon that is responsible for widespread losses mainly in
TABLE 1: Sectors of the drainage areas studied.

\begin{tabular}{lc}
\hline Sector & Name \\
\hline S1 & Northwestern area of the Salado River basin \\
S9 & Arrecifes River basin \\
S12 & Region without surface drainage \\
\hline
\end{tabular}

agriculture. It occurs in virtually all climatic zones, such as high as well as low rainfall areas and is mostly related to the reduction in the amount of precipitation received over an extended period of time, such as a season or a year [9]. Some characteristics of other climate elements, like high temperatures; high winds; low relative humidity; timing and characteristics of rains, including distribution of rainy days during crop growing seasons, intensity and duration of rain, and onset and termination, play a significant role in the occurrence of droughts and influencing the evapotranspiration. A decline of soil moisture depends on several factors which affect meteorological and hydrological droughts along with differences between actual evapotranspiration and potential evapotranspiration [10].

A component of the soil water balance, the soil water deficit, usually refers to a period with declining soil moisture and consequent crop failure without any reference to surface water resources and to agricultural drought.

Scarpati et al. [11] found that water surpluses occur in almost all years, but they are particularly marked during the El Niño phase of ENSO and least during La Niña. Scarpati et al. [12] showed that the north area of the province has higher soil water content in years of ENSO warm phase than in years with ENSO cold phase, and there are no differences in areas close to De La Plata River.

The goal of this paper is to analyze the extreme hydrologic events in the north area of Buenos Aires province considering the soil water surplus and soil water deficit as triggers of them.

\section{Materials and Methods}

2.1. Study Area. Figure 1 shows the Buenos Aires province, Figure 2 shows its hydrology, and Figure 3 and Table 1 show the studied drainage areas or sectors (S1, S9, and S12) of this province according to the digital Atlas provided by the National Water Resources [13].

2.2. Data and Meteorological Stations. Daily precipitation data for the period 1971-2010 were provided by the National Meteorological Service (SMN) (29 stations) and by the National Institute of Agronomic Technology (INTA) (5 stations). The meteorological stations were selected according to their long record, homogeneity, and historical development. Figure 4 shows the studied area with the meteorological stations used listed in Table 2.

2.3. Assumed Concepts Referring to Soil Water Balance. The spatial and temporal variability of soil water storage was examined by means of software which calculates the soil 
TABLE 2: Denomination and code of the meteorological stations.

\begin{tabular}{|c|c|}
\hline Number & Station \\
\hline 1 & San Pedro INTA \\
\hline 2 & Pergamino INTA \\
\hline 3 & Junin \\
\hline 4 & San Miguel \\
\hline 5 & Mariano Moreno \\
\hline 6 & Aeroparque J. Newbery \\
\hline 7 & Buenos Aires \\
\hline 8 & Ezeiza \\
\hline 9 & General Villegas \\
\hline 10 & La Plata \\
\hline 11 & Nueve de Julio \\
\hline 12 & Punta Indio \\
\hline 13 & Pehuajó \\
\hline 14 & Trenque Lauquen \\
\hline 15 & Las Flores \\
\hline 16 & Bolivar \\
\hline 17 & Dolores \\
\hline 18 & Daireaux \\
\hline 19 & Santa Teresita \\
\hline 20 & Azul \\
\hline 21 & Olavarría \\
\hline 22 & Tandil \\
\hline 23 & Villa Gesell \\
\hline 24 & Coronel Suarez \\
\hline 25 & Laprida \\
\hline 26 & Pigüé \\
\hline 27 & Benito Juárez \\
\hline 28 & Balcarce INTA \\
\hline 29 & Bordenave INTA \\
\hline 30 & Coronel Pringles \\
\hline 31 & Mar del Plata \\
\hline 32 & Tres Arroyos \\
\hline 33 & Bahía Blanca \\
\hline 34 & Hilario Ascasubi INTA \\
\hline
\end{tabular}

water balance of Forte Lay et al. [4]. This is based on Thornthwaite and Mather daily soil water balance method, using measured precipitation from the meteorological stations and daily mean reference evapotranspiration. The normal daily mean reference evapotranspiration was estimated by the Penman-Monteith formula [14].

Equation (1) shows that the model of soil water balance used is

$$
\mathrm{PP}-\mathrm{EP}+\Delta \mathrm{St}+\mathrm{Su}+\mathrm{Def}=0,
$$

where PP is daily precipitation; EP is mean reference evapotranspiration; $\Delta \mathrm{St}$ is soil water storage variation; $\mathrm{Su}$ is soil water surplus; Def is soil water deficit.

The soil hydrologic constants, field capacity (FC) and permanent wilting point (PWP), were those used by Forte Lay et al. [4], with soil data measured "in situ."

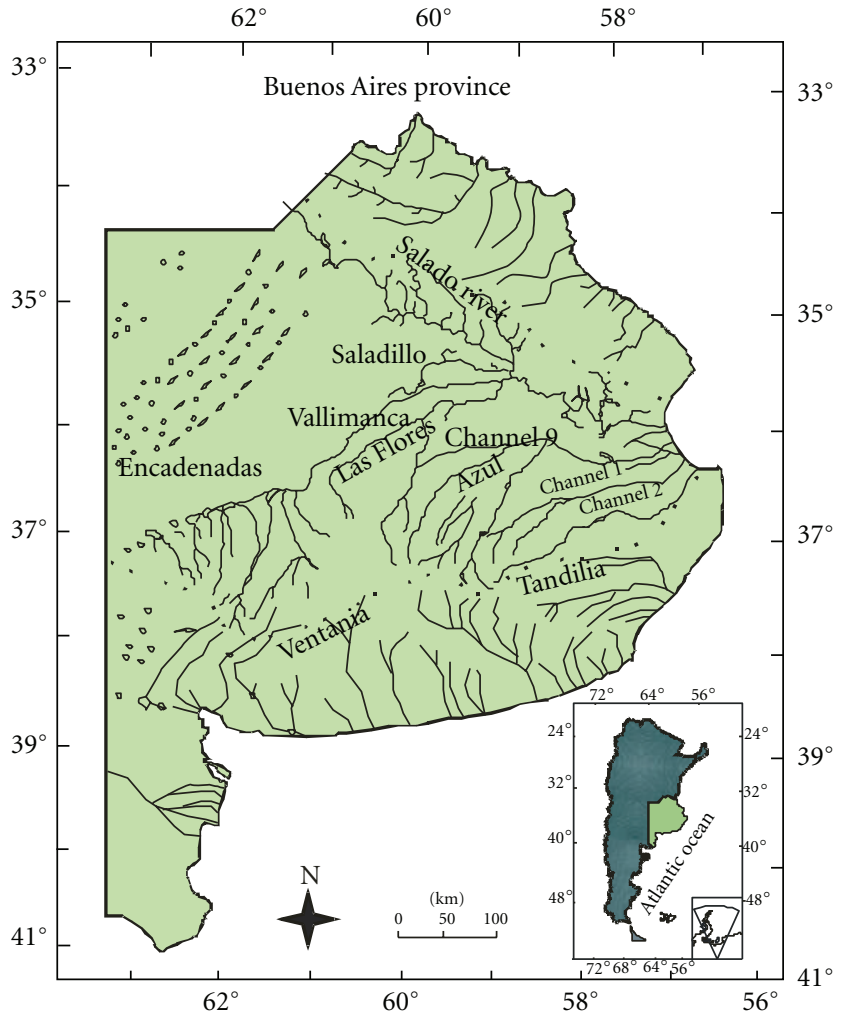

FIgUre 2: Buenos Aires province and its hydrology.

The total soil moisture can be divided into two equal parts: the available soil water content and the nonuseful water, as can be seen in Figure 5 .

The available soil moisture, as well, can be divided into two parts: the optimum soil water content (50 to $100 \%$ of useful water) and the conditional drought level (0 to $50 \%$ of useful water).

The absolute drought is when soil has $0 \%$ of useful water. The permanent wilting point (PWP) is the limit between the last two ones, and the conditional drought level represents the upper limit of drought according to Scarpati et al. [15].

All these parameters vary according the soil texture and the effective depth (root zone), which depends on a restrictive horizon existence. Some soils with high effective depth reach one meter or more and have high FC. Other soils, with low effective depth root zone, only reach lower depths, and then the FC diminishes.

The soil water balance was realized for all the used stations, for every year of the studied period, and so all the annual areal values of soil water deficit were obtained.

The meteorological station Junin $\left(34^{\circ} 33^{\prime} \mathrm{S} 60^{\circ} 55^{\prime} \mathrm{W}\right.$, $81 \mathrm{~m}$; number 3 in Table 2 and Figure 4) was selected as an example of the behaviour and temporal evolution of the soil water surplus and the soil water deficit $y$.

2.4. Maps Construction. The maps showing the soil water deficit and soil water surplus as results of soil water balance of each meteorological station, for every year of the studied period, were performed using the software SURFER 8.0. This 


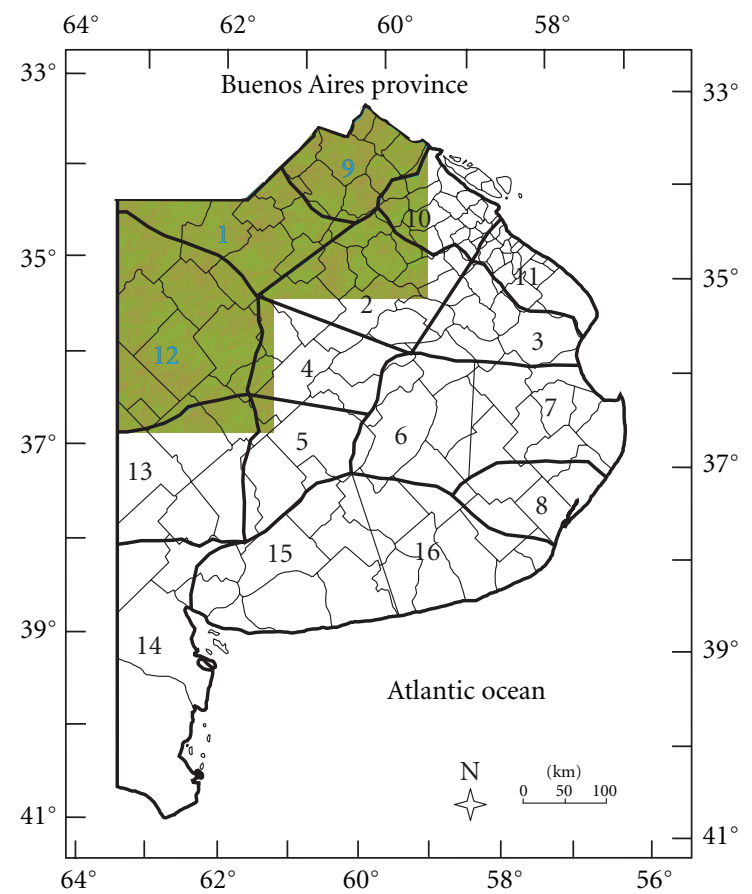

FIgURe 3: Buenos Aires province and its drainage areas.

TABle 3: Classification of ASWS.

\begin{tabular}{lcccc}
\hline ASWS $(\mathrm{mm})$ & $\leq 100$ & $>100$ and $\leq 200$ & $>200$ and $\leq 300$ & $>300$ \\
Surplus & Mild & Moderate & Severe & Extreme \\
\hline
\end{tabular}

mapping software allows the construction of isolines maps using its Kriging option (the Point Kriging estimates the values of the points at the grid nodes).

2.5. Soil Water Surplus. The obtained maps allow the observation of spatial distribution of the annual soil water surplus (ASWS). The temporal distribution was analyzed considering an average areal value for each studied sector of Table 1 and for each year. The average areal value was obtained by geographical interpolation.

An annual mean areal value of $300 \mathrm{~mm}$ of soil water surplus is considered as threshold, upon which the damage for flood is the consequence.

The next classification of ASWS is applied to the results, and so four types of flood risk are obtained (see Table 3).

2.6. Soil Water Deficit. Other resulting maps permit the observation of the annual soil water deficit spatial distribution. Then, the temporal distribution was analyzed considering an average areal value for each drainage area of Table 1 and for each year.

An annual mean areal value of $200 \mathrm{~mm}$ of soil water deficit is considered as threshold, upon which the damage for drought is the consequence. This value is considered because it is an ecological limit.

In this paper, the drought has been classified as mild, moderate, severe, and extreme according to the annual soil

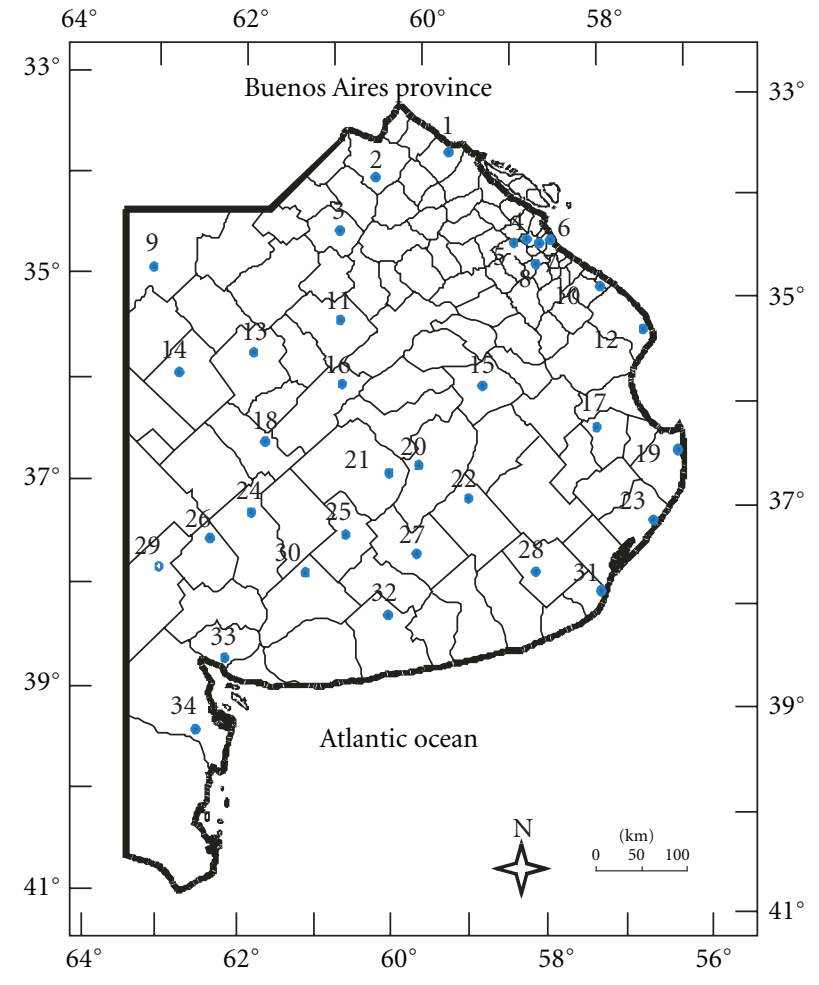

FIgURE 4: Meteorological stations location.

TABLE 4: Classification of ASWD.

\begin{tabular}{llccr}
\hline ASWD $(\mathrm{mm})$ & $\leq 200$ & $>200$ and $\leq 300$ & $>300$ and $\leq 400$ & $>400$
\end{tabular}

water deficit (ASWD) values reached, as can be seen in Table 4 .

2.7. Statistical Analysis. The series of soil water surplus and soil water deficit data were adjusted by means of the theoretical normal cubic root probability distribution.

The nonparametric test Mann-Kendall is applied for all the data series, and then, an Excel template-MAKESENSis used for detecting and estimating trends in the time series of annual values of soil water deficit [16]. The procedure is based on the nonparametric Mann-Kendall test for the trend and the nonparametric Sen's method for the magnitude of the trend. First, the Mann-Kendall test is applicable to the detection of a monotonic trend of a time series with no seasonal or other cycle, and then the Sen's method uses a linear model for the trend (2). In MAKESENS, the tested significance levels $\alpha$ are $0.001,0.01,0.05$, and 0.1 [17]:

$$
f(t)=Q t+B,
$$

where $Q$ is the slope, and $B$ is a constant.

The Mann-Kendall test is a nonparametric rank-based method which does not require the normal distribution of data. It is robust to the effects of outliers and allows existence of missing data (as only ranks are used). The basic principle of Mann-Kendall test for detecting a trend in a time series is 


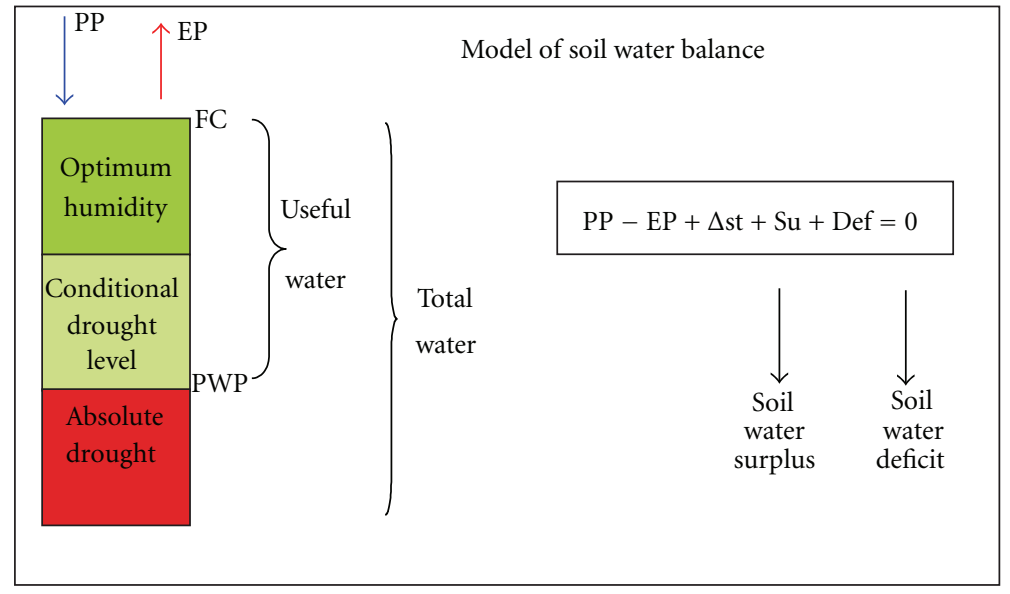

FIGURE 5: Soil water balance.

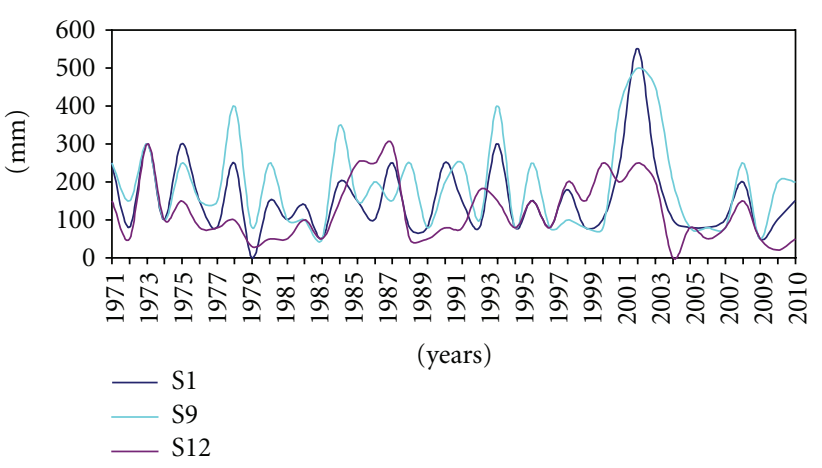

Figure 6: Annual soil water surplus (mm) from 1971 to 2010.

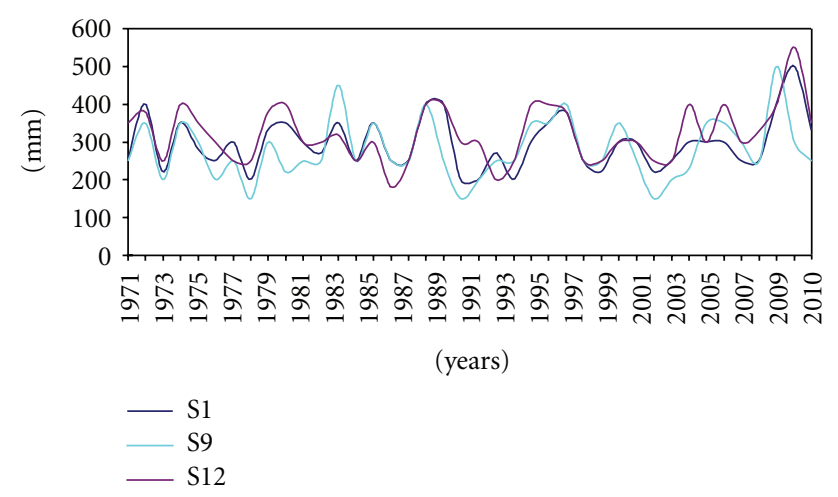

Figure 7: Annual soil water deficit (mm) from 1971 to 2010.

to examine the sign of all pairwise differences of observed values. The Mann-Kendall test has been widely used to detect trends in hydrometeorological time series and is well documented in the literature [18].

\section{Results and Discussion}

Figures 6 and 7 present the annual evolution of soil water surplus and soil water deficit, respectively. The three drainage areas have annual oscillations; the variations are more

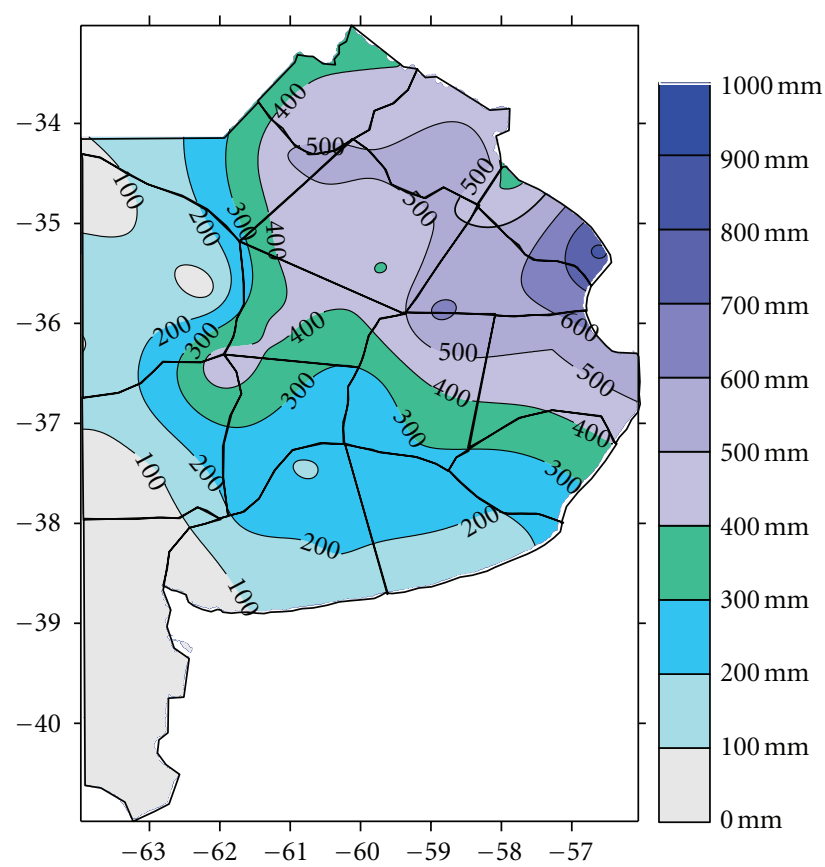

FIgURE 8: Soil water surplus (mm) during 1993.

important in Figure 6 than in Figure 7, and in it the three lines go together.

Figures 8 and 9 show the annual soil water surplus during 1993 and 2001 for the whole Buenos Aires province. At the studied region, in 1993 the values oscillated between lower than $100 \mathrm{~mm}$ and $500 \mathrm{~mm}$. The highest values were at S9 (Arrecifes River basin) and the lowest at S12 (region without surface drainage). The values reached in 2001 were 600 $500 \mathrm{~mm}$ in S1, $600 \mathrm{~mm}$ to $300 \mathrm{~mm}$ in S9, and 400 to 300 in S12. These years presented very important floods during the studied period [19-21].

Figures 10 and 11 the present annual soil water deficit reached during 1995 and 2008, respectively. 


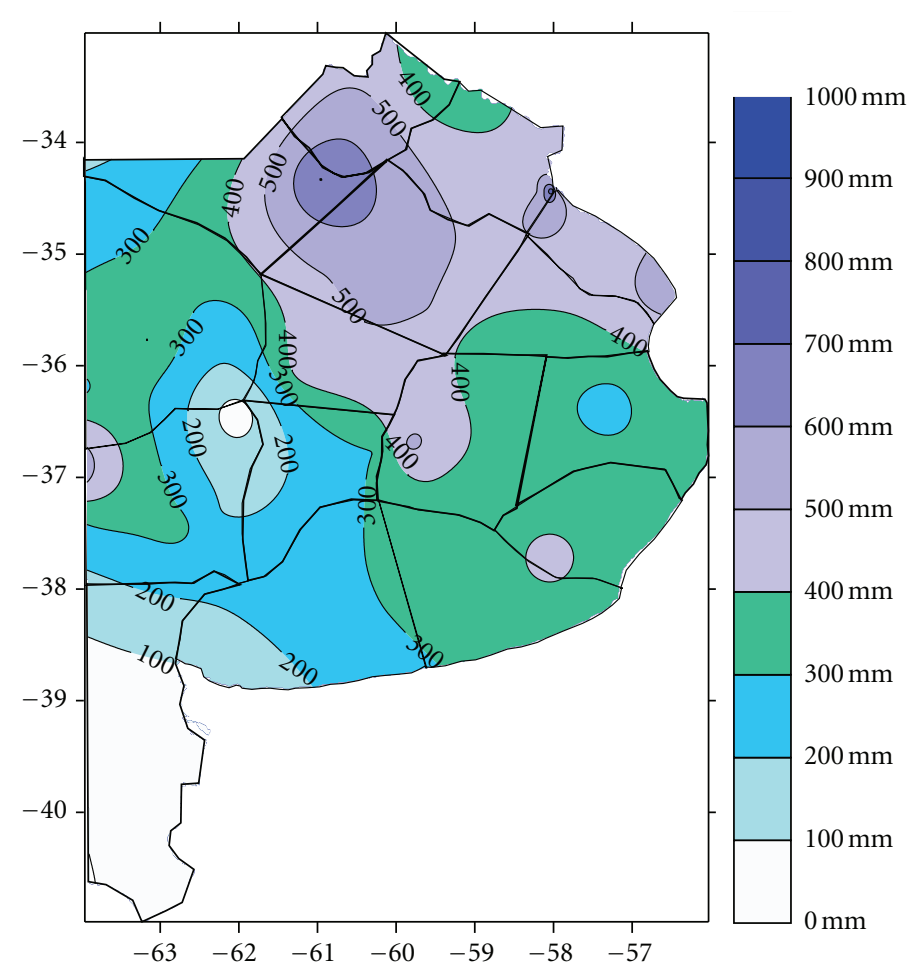

Figure 9: Soil water surplus (mm) during 2001.

TABLE 5: Distribution of the different types of flood at the different drainage areas.

\begin{tabular}{lcccc}
\hline Flood & Mild & Moderate & Severe & Extreme \\
\hline S1 & 20 & 10 & 9 & 1 \\
S9 & 16 & 10 & 8 & 6 \\
S12 & 23 & 11 & 6 & 0 \\
\hline
\end{tabular}

The values of soil water deficit of the last drought (2008) were higher than those of 1995. In 1995, the values oscillated between 500 and $300 \mathrm{~mm}$ while in 2008 they were always higher than $400 \mathrm{~mm}$ in the studied region. In both figures, the values of soil water deficit were higher in S12 (region without surface drainage) than in the other two, and the lowest values were in S9 (Arrecifes River basin).

Table 5 shows the classification of flood occurred from 1971 to 2010; all types described took place in the three sectors with the exception of extreme flood in S12. This one, region without surface drainage, had a lower number of these events than the other drainage areas. S1 (northwestern area of the Salado River basin) had more severe flood events and only one extreme, while S9 (Arrecifes River basin) had six extreme floods.

Table 6 presents the distribution of the drought types registered in the studied period. The highest values are found in moderate droughts, and the sectors had only one or two extreme droughts.

Table 7 shows the temporal distribution and trends of soil water surplus of the three studied sectors. The analyzed
TABle 6: Distribution of the different types of drought at the different drainage areas.

\begin{tabular}{lcccc}
\hline Drought & Mild & Moderate & Severe & Extreme \\
\hline S1 & 4 & 22 & 13 & 1 \\
S9 & 7 & 20 & 10 & 2 \\
S12 & 1 & 21 & 17 & 1 \\
\hline
\end{tabular}

TABLE 7: Trends and temporal distribution of soil water surplus.

\begin{tabular}{lccc}
\hline Period & & Sector & \\
& S1 & S9 & S12 \\
\hline $1971-2010$ & $=$ & $\downarrow$ & $=$ \\
$1971-1990$ & $\downarrow$ & $\downarrow$ & $=$ \\
$1991-2010$ & $=$ & $=$ & $\downarrow$ \\
$1971-1980$ & $\downarrow$ & $\uparrow$ & $\downarrow$ \\
$1981-1990$ & $\uparrow$ & $=$ & $\uparrow$ \\
$1991-2000$ & $=$ & $\downarrow$ & $\downarrow$ \\
$2001-2010$ & $\downarrow$ & $\downarrow$ & \\
\hline
\end{tabular}

$\downarrow$ Diminution, $\uparrow$ increase, $=$ no variation, and + significant trend at levels $\alpha=0.1,{ }^{*} \alpha=0.05$, and ${ }^{* *} \alpha=0.01$.

periods were 1971-2010, 1971-1990, 1991-2010, 1971-1980, 1981-1990, 1991-2000, and 2001-2010, and as can be seen there were no significant results at any period independent of its length (ten, twenty, thirty, or forty years).

Table 8 shows the trends and the temporal distribution of soil water deficit for the period 1971-2010. In this case, there are significant positive results for the periods 1991-2010 and 


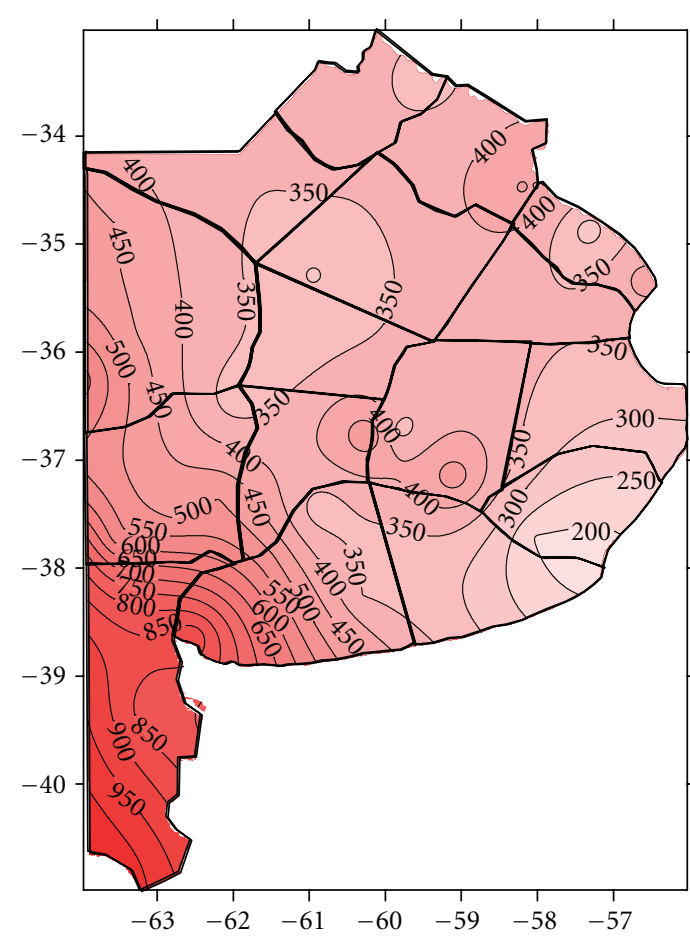

Figure 10: Soil water deficit (mm) during 1995.

TABLE 8: Trends and temporal distribution of soil water deficit.

\begin{tabular}{lccc}
\hline Period & & Sector & \\
& S1 & S9 & S12 \\
\hline $1971-2010$ & $=$ & $=$ & $=$ \\
$1971-1990$ & $=$ & $=$ & $=$ \\
$1991-2010$ & $+\uparrow$ & $=$ & $+\uparrow$ \\
$1971-1980$ & $\uparrow$ & $\downarrow$ & $=$ \\
$1981-1990$ & $=$ & $=$ & $=$ \\
$1991-2000$ & $\uparrow$ & $=$ & $+\uparrow$ \\
$2001-2010$ & $+\uparrow$ & $\uparrow$ &
\end{tabular}

$\downarrow$ Diminution, $\uparrow$ increase, $=$ no variation, and + significant trend at levels $\alpha=0.1,{ }^{*} \alpha=0.05$, and ${ }^{* *} \alpha=0.01$.

2001-2010 ( $\alpha=0.1)$ in sector 1 (northwestern area of the Salado River basin). S12 (region without surface drainage) has the same results.

Trends are not statistically significant for flood and drought during the total studied period (1971-2010). The three sectors remain stable.

Soil water surplus has no statistical significance for any analyzed period and sector.

Soil water deficit increasing became significant since 1991 when apparently the wet period had begun to finalize in the northwestern area of the Salado River basin (S1) and in the region without surface drainage (S12). This is not the case of the Arrecifes River basin (S9) where there were no important changes in any period.

Table 9 shows the temporal distribution and trends of soil water surplus and of soil water deficit in Junin. The

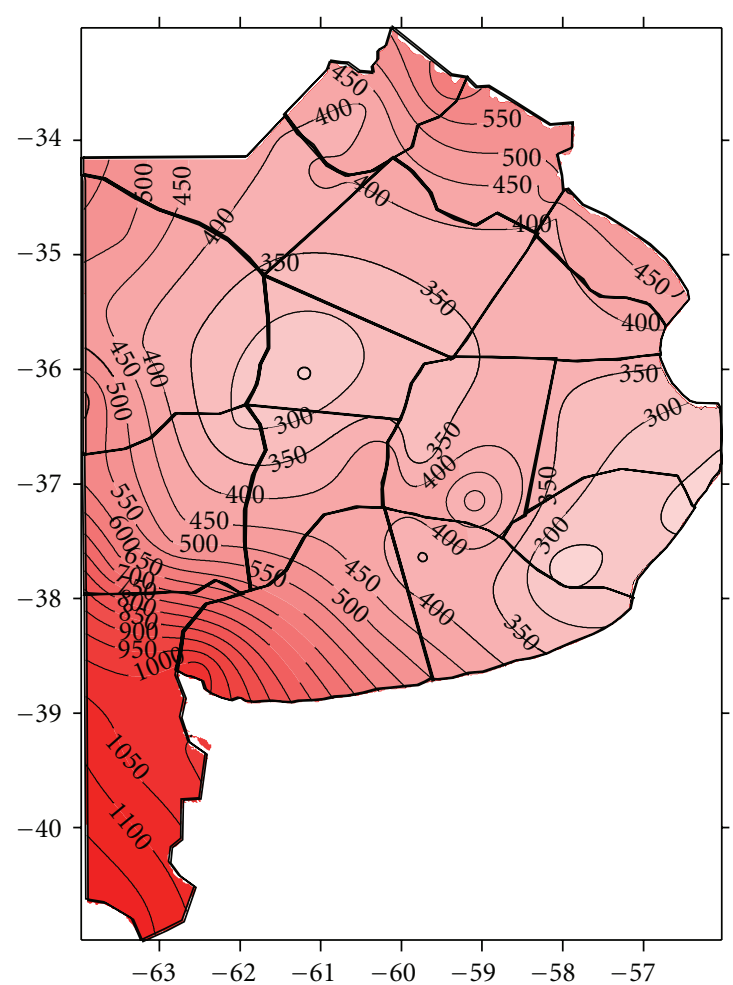

FIgURe 11: Soil water deficit (mm) during 2008.

TABLE 9: Trends and temporal distribution of soil water surplus and of soil water deficit in Junin.

\begin{tabular}{lcc}
\hline Period & Soil water surplus & Soil water deficit \\
\hline $1971-2010$ & $\uparrow$ & $\downarrow$ \\
$1971-1990$ & $\uparrow$ & $\downarrow$ \\
$1991-2010$ & $\uparrow$ & $\uparrow$ \\
$1971-1980$ & $\uparrow$ & $\downarrow$ \\
$1981-1990$ & $\uparrow$ & $\uparrow$ \\
$1991-2000$ & $\downarrow$ & $\uparrow$ \\
$2001-2010$ & $\downarrow$ & $+\uparrow$
\end{tabular}

$\downarrow$ Diminution, $\uparrow$ increase, and + significant trend at level $\alpha=0.1$.

Table 10: Distribution of the different types of flood at Junin during 1971-2010.

\begin{tabular}{lccc}
\hline & & Flood & \\
Mild & Moderate & Severe & Extreme \\
\hline 17 & 8 & 9 & 6 \\
\hline
\end{tabular}

only statistical significant trend is the last one during the last decade (2001-2010).

Tables 10 and 11 present the results of the classifications for flood and drought for Junin during the studied period.

From the data series, it can be said that the highest values of annual soil water surplus were $702.7 \mathrm{~mm}$ in 2001 and 510.1 in 1993 while the highest values of annual soil water deficits were $448.1 \mathrm{~mm}$ in 1972 and $405.8 \mathrm{~mm}$ in 2008. 
TABle 11: Distribution of the different types of drought at Junin during 1971-2010.

\begin{tabular}{lccc}
\hline & \multicolumn{2}{c}{ Drought } & \\
Mild & Moderate & Severe & Extreme \\
\hline 9 & 16 & 13 & 2 \\
\hline
\end{tabular}

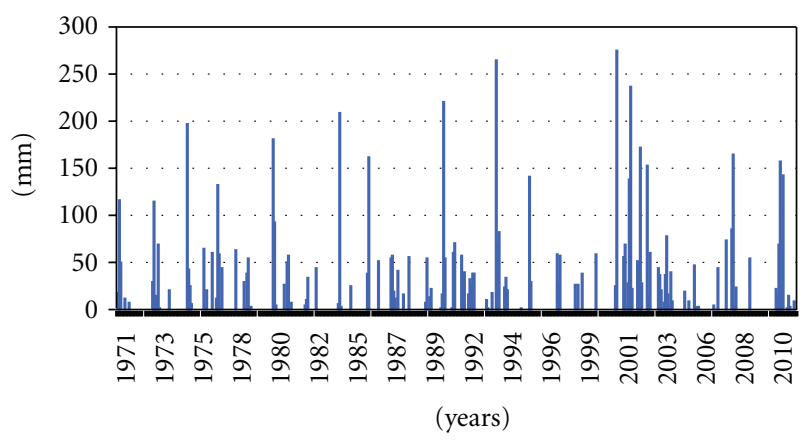

Figure 12: Evolution of monthly soil water surplus (mm) in Junin.

Figures 12 and 13 show the evolution of monthly soil water surplus and soil water deficit in Junin from January 1971 to December 2010, respectively.

Soil water deficit is a more constant parameter almost every year drought risk and its values can be found.

\section{Conclusions}

The results of this study are a new approach of extreme hydrologic events occurred in the northern region of Buenos Aires province, and they could be useful in hazards' warning and decision-making.

The increase in precipitation since 1970 shifted westward the agricultural frontier about $200 \mathrm{~km}$, being thus substantially favoured farming in certain semiarid areas as S12.

The period 2000-2003 showed high soil water surplus values in the drainage areas $\mathrm{S} 1$ and $S 9$, which produced important losses both in rural and urban areas.

The sector S9 had several years with soil water surplus higher than $300 \mathrm{~mm}$, but its edaphic characteristics are better than those of S1. For this, S1 suffered more easily flood risk.

The years 2008 and 2009 had the highest values of soil water deficit with important losses. The increasing drought trends of the periods 1991-2010 and 2001-2010 were statistically significant at level $\alpha=0.1$ for S1 and S12.

Severe and extreme events for floods were 10 in S1, 14 in S9, and 6 in S12 while for droughts were 14 in S1, 12 in S9, and 18 in S12.

When the events were studied in Junin, it can be said that as precipitation was important in the last months of the year 2000 , and so, in 2001 the annual soil water surplus reached the high value of $702.7 \mathrm{~mm}$. The sum of mild and moderate flood and drought 25, and the sum of severe and extreme of both events was 15 .

The extreme hydrologic events always have different areal distribution, but according to the precipitation pattern, the Region without surface drainage (S12) always had lower

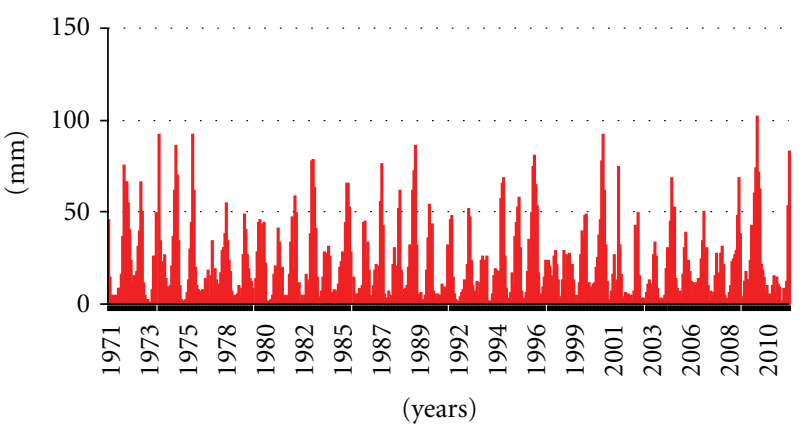

FIgURE 13: Evolution of monthly soil water deficit (mm) in Junin.

values of soil water surplus than the other two studied drainage areas: northwestern area of the Salado River basin (S1) and the Arrecifes River basin (S9).

Flood events trend did not have statistical significance at any studied period, but drought trends were significant at level $\alpha=0.1$ in two different periods and in two sectors (S1 and S12).

The period 2001-2010 presented extreme hydrologic events (flood and drought) with highest annual values, considering the total analyzed period. It can be related to climate global change and the alternance of both hazards.

\section{References}

[1] J. C. Labraga, B. Scian, and O. Frumento, "Anomalies in the atmospheric circulation associated with the rainfall excess or deficit in the Pampa region in Argentina," Journal of Geophysical Research D, vol. 107, no. 23, pp. 1-15, 2002.

[2] V. R. Barros, M. E. Castañeda, and M. Doyle, "Recent precipitation trends in Southern South America East of the Andes: an indication of climatic variability," in Southern Hemisphere Paleo and Neoclimates, P. P. Smolka and W. Volkheiner, Eds., pp. 187-206, Springer, Berlin, Germany, 2000.

[3] M. R. Haylock, T. C. Peterson, L. M. Alves et al., "Trends in total and extreme South American rainfall in 1960-2000 and links with sea surface temperature," Journal of Climate, vol. 19, no. 8, pp. 1490-1512, 2006.

[4] J. Forte Lay, O. E. Scarpati, and A. Capriolo, "Precipitation variability and soil water content in pampean flatlands (Argentina)," Geofisica Internacional, vol. 47, no. 4, pp. 341354, 2008.

[5] E. Kruse, J. A. Forte Lay, J. L. Aiello, A. Basualdo, and G. Heinzenknecht, "Hydrological processes on large flatlands: case study in the Northwest region of Buenos Aires Province (Argentina)," in Proceedings of the International Symposium on Remote Sensing and Hydrology, vol. 267 of IAHS Publications, pp. 531-535, April 2000.

[6] J. A. Forte Lay, E. Kruse, and J. L. Aiello, "Hydrologic scenarios applied to the agricultural management of the Northwest of the Buenos Aires Province, Argentina," GeoJournal, vol. 70, no. 4, pp. 263-271, 2007.

[7] J. A. Forte Lay, O. E. Scarpati, and A. D. Capriolo, “The 20002002 flood event in Buenos Aires province, Argentina," Journal of Flood Engineering, vol. 1, no. 1, pp. 29-40, 2009.

[8] E. D. Hunt, K. G. Hubbard, D. A. Wilhite, T. J. Arkebauer, and A. L. Dutcher, "The development and evaluation of a soil moisture index," International Journal of Climatology, vol. 29, no. 5, pp. 747-759, 2009. 
[9] A. K. Mishra and V. P. Singh, "A review of drought concepts," Journal of Hydrology, vol. 391, no. 1-2, pp. 202-216, 2010.

[10] A. D. Capriolo and O. E. Scarpati, "Modeling the distribution of agricultural drought by means of soil water deficit," Energy and Environment Research, vol. 2, no. 2, p. 1, 2012.

[11] O. E. Scarpati, J. A. Forte Lay, L. Spescha, and A. D. Capriolo, "Autumn soil water surplus during ENSO events in Argentine pampean flatlands," in Managing Water Resources in a Changing Physical and Social Environment, P. J. Robinson, M.-K. Woo, and J. A. A. Jones, Eds., Home of Geography Publication Series, part 2, chapter 4, pp. 27-36, Società Geografica Italiana, Rome, Italy, 2007.

[12] O. E. Scarpati, J. A. Forte Lay, L. Spescha, and A. D. Capriolo, "Summer soil water storage in Pampean Flatlands (Argentina) during ENSO events," in The Rational Use and Conservation of Water Resources in a Changing Environment, J. A. A. Jones and T. Vardanian, Eds., vol. 1, pp. 38-42, Yerevan State University Press, 2004.

[13] Argentina. SSRH-INA, Atlas Digital de los Recursos Hídricos Superficiales de la República Argentina. CD-Rom. Subsecretaría de Recursos Hídricos de la Nación - Instituto Nacional del Agua, Buenos Aires, Argentina. 2002.

[14] R. G. Allen, L. S. Pereira, D. Raes, and M. Smith, Crop Evapotranspiration. Guidelines for Computing Crop Water Requirements, vol. 56, FAO. Irrigation and Drainage, Rome, Italy, 2004.

[15] O. Scarpati, J. Forte Lay, and A. Capriolo, "Drought risk in Argentine pampean region," International Journal of Ecology \& Development, vol. 18, no. 11, pp. 1-18, 2011.

[16] T. Salmi, A. Määttä, P. Anttila, T. Ruoho-Airola, and T. Amnell, Detecting Trends of Annual Values of Atmospheric Pollutants by the Mann-Kendall Test and Sen's Slope Estimates: The Excel Template Application MAKESENS, Publication on Air Quality, Finnish Meteorological Institute, no. 31, Helsinki, Finland, 2002.

[17] S. Liu, X. Mo, W. Zhao et al., "Temporal variation of soil moisture over the Wuding river basin assessed with an ecohydrological model, in-situ observations and remote sensing," Hydrology and Earth System Sciences, vol. 13, no. 7, pp. 13751398, 2009.

[18] E. Eris and N. Agiralioglu, "Homogeneity and trend analysis of hydrometeorological data of the Eastern Black Sea Region, Turkey," Journal of Water Resource and Protection, vol. 4, pp. 99-105, 2012.

[19] O. E. Scarpati, L. Spescha, and A. Capriolo, "Occurrence of severe floods in the Salado river basin, Buenos Aires province, Argentina," Mitigation and Adaptation Strategies for Global Change, vol. 7, no. 3, pp. 285-301, 2002.

[20] M. H. González and A. E. Fernández, "Floods increasing in Buenos Aires Salado river basin, Argentina," in Environmental Change and Rational Water Use, J. A. A. Jones and O. E. Scarpati, Eds., session 1, pp. 96-113, 2007.

[21] O. E. Scarpati, J. A. F. Lay, and A. D. Capriolo, "La inundación del año 2001 en la Provincia de Buenos Aires, Argentina," Mundo Agrario, vol. 9, no. 17, 2008. 

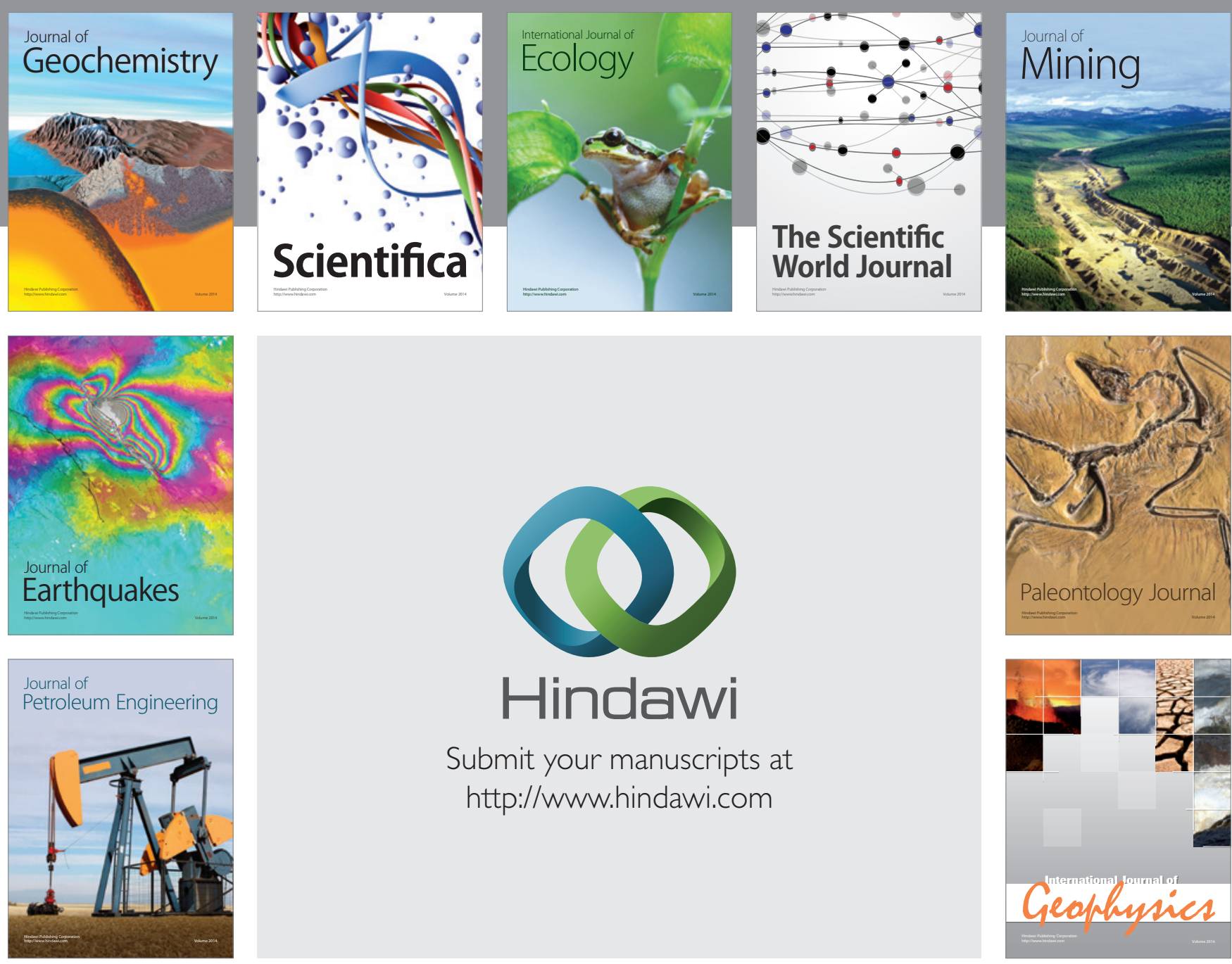

Submit your manuscripts at

http://www.hindawi.com
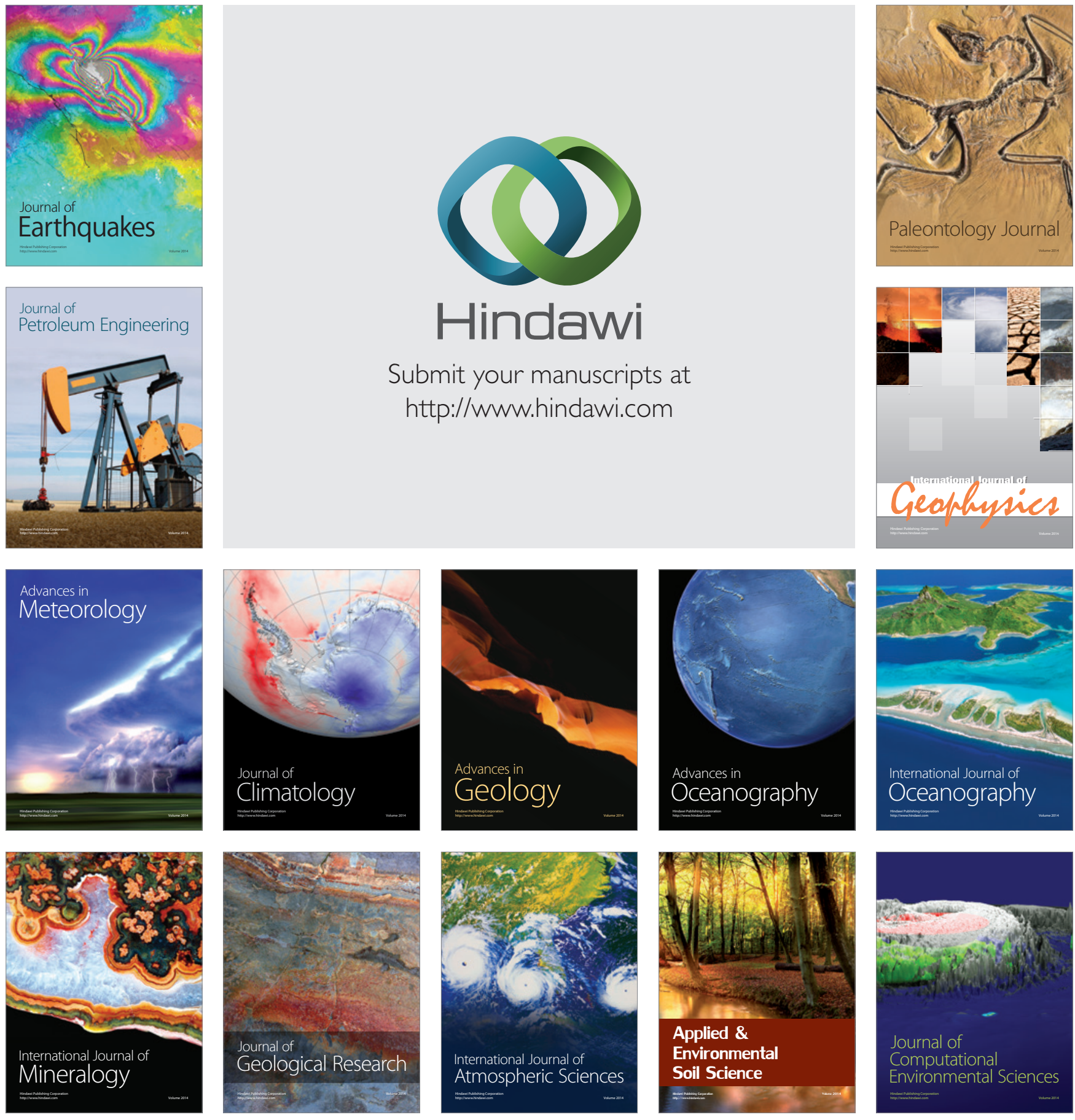